\title{
Spray drying as a method for preparing concentrated cultures of Lactobacillus bulgaricus
}

\author{
P. Teixeira, H. Castro and R. Kirby \\ Escola Superior de Biotecnologia, Universidade Católica Portuguesa, Porto, Portugal
}

\begin{abstract}
P. TEIXEIRA, H. CASTRO AND R. KIRBY. 1995. Spray drying and freeze drying as methods for concentration of Lactobacillus bulgaricus starter cultures were compared in terms of viability, lag phase until onset of $\mathrm{pH}$ decrease and total acid production. For the experimental conditions used, no significant differences were detected between the methods.

The effect of spray drying on the cell membrane of Lactobacillus bulgaricus was studied. Five separate methods were used to study the theory that spray drying causes cell membrane damage; three relating to leakage of intracellular components from the cell into the surrounding environment ( 260 and $280 \mathrm{~nm}$ absorbing materials, potassium ions and proteins); and two relating to increased cell permeability (increased sensitivity to $\mathrm{NaCl}$ and increased permeability to 0 -nitrophenyl- $\beta$-D-galactopyranoside (ONPG). Partial loss of some cytoplasmic material from the damaged cells was observed. The dried cells also became sensitive to $\mathrm{NaCl}$ and permeable to ONPG. Heat shock increased the survival of exponential cells as compared to controls but did not result in normal levels found with unshocked stationary phase cells. Heat shock had no effect on stationary phase cells. Different rehydration methods and media were investigated : slow rehydration increased survival.
\end{abstract}

\section{INTRODUCTION}

Several investigators have considered the possibility of drying large quantities of bacterial cultures, with the idea of using it as a method to replace the usual liquid bulk starter in the production of fermented dairy products (Rogers 1914; Mamaeva 1956; Porubcan and Sellars 1975; Gilliland 1976). For this purpose spray drying would be preferable to freeze drying because of the lower cost (Foster 1962). The spray drying of micro-organisms dates back to 1914 to the work of Rogers (1914) with dried milk cultures of lactic acid bacteria. Since then much research has been performed on the use of spray drying of bacteria in order to overcome the work involved in maintaining liquid stock cultures and to facilitate the dispatch of dried cultures by post without any loss in their activity (Prajapati $e t$ al. 1987). Although this process proved promising, it has not been developed commercially for use with lactic acid bacteria. Reasons for this are mainly low survival rates during drying of the cultures, low stability under storage and the difficulty in rehydrating the product. Each of the above areas has received much attention in the literature. For reviews

Correspondence to: Dr Roy Kirby, Escola Superior de Biotecnologia, R. Dr Antíno Bernardino de Almeida, 1200 Porto, Portugal. in spray drying conditions see Espina and Packard (1979) and Kim and Bhowmik (1990), low stability under storage see Mamaeva (1956) and Porubcan and Sellars (1975), and rehydration conditions see Richardson (1960). There is little information available regarding the mechanism(s) of cell inactivation.

The objective of this study was to compare the survival of Lactobacillus bulgaricus during spray drying and freeze drying. Damage during spray drying is unlikely to be repaired during the subsequent phase of storage or rehydration. This damage and the inability of the cells to repair it would be expected to prejudice the survival of the bacteria during these phases, the totality of damage caused being the likely cause of the increased lag phase commonly reported for these bacteria.

In order to fully examine the survival of Lact. bulgaricus during spray drying and to try to define optimal process parameters in relation to the bacteria themselves the following studies were performed:

- Membrane damage: has been reported as a site of damage common to different type of stresses: freeze drying (Morichi et al. 1967), freeze and vacuum drying (Brennan et al. 1986) and heat treatments (Hurst and Hughes 1975; Hoover and Gray 1977). 
- Growth phase: it is well known that cells at exponential phase of growth are more sensitive to treatments such as heating (Griffiths and Haigh 1973; Hurst et al. 1974; Teixeira et al. 1994).

- Heat shock: it has been reported that heat shock can increase the resistance of different bacteria to heat treatments (Hogg 1989; Whitaker and Batt 1991; Teixeira et al. 1994).

- Rehydration: the rehydration of dried bacterial cells is a critical process which sometimes affects the cell viability (Morichi et al. 1967); however, the rehydration methods actually used by earlier workers have not always been described. The reasons for using determined conditions by some workers have, in general, not been supported by comparisons with alternative procedures.

\section{MATERIALS AND METHODS}

\section{Organism}

Lactobacillus delbrueckii subsp. bulgaricus NCFB 1489 was used. Cultures were maintained as in Teixeira et al. (1994).

\section{Media}

All media were prepared using deionized water and sterilized by autoclaving for $15 \mathrm{~min}$ at $121^{\circ} \mathrm{C}$.

Diluent: AM buffer was prepared by mixing $0.01 \mathrm{~mol}$ $1^{-1} \mathrm{~K}_{2} \mathrm{HPO}_{4}$ and $0.01 \mathrm{~mol} \mathrm{l}^{-1} \mathrm{KH}_{2} \mathrm{PO}_{4}$ (Merck), both dissolved in a solution of $0.15 \mathrm{~mol} 1^{-1} \mathrm{NaCl}$ (Merck), adjusted to $\mathrm{pH} 7 \pm 0 \cdot 1$ and sterilized.

The complex media used for batch growth of Lact. bulgaricus was MRS broth prepared and sterilized according to the manufacturer's instructions.

\section{Preparation of cultures}

MRS broth was inoculated from the MRSA slopes and incubated for $24 \mathrm{~h}$ at $42^{\circ} \mathrm{C}$. This broth was then used to inoculate a second MRS broth $(1 \% \mathrm{v} / \mathrm{v})$. The cultures were incubated at $42^{\circ} \mathrm{C}$ for $6 \mathrm{~h}$ (exponential phase cells) or $16 \mathrm{~h}$ (stationary phase cells) in a shaken water bath. Cells were harvested by centrifugation at $10000 \mathrm{~g}$ for $10 \mathrm{~min}$ at $4^{\circ} \mathrm{C}$ and washed with sterile AM buffer.

\section{Heat shock treatment}

Cell pellet was resuspended in $50 \mathrm{ml}$ of skim milk ( $11 \%$ solids) previously equilibrated at $50^{\circ} \mathrm{C}$ (test cells) and $50 \mathrm{ml}$ at $37^{\circ} \mathrm{C}$ (control cells) and left for 30 min under agitation in a shaken water bath. Heat-shocked cell suspension and control cells were then spray dried.

\section{Spray drying}

Forty per cent maltodextrin (Glucidex 12, Roquette, Lille, France) in deionized water or skim milk (11\% solids) was inoculated with Lact. bulgaricus cultures. This suspension was incubated for $30 \mathrm{~min}$ at $37^{\circ} \mathrm{C}$ to allow for cell adaptation, constantly agitated and then spray dried. Samples were spray dried in a laboratory scale spray drier (Niro Atomizer). Moisture in spray droplets produced by the atomization of the feed liquid into a spray by the use of a vaned wheel rotating at high speed was evaporated in a vertical, cocurrent drying chamber $(0.8 \mathrm{~m}$ diam. and $0.6 \mathrm{~m}$ height). The air temperatures at the inlet and outlet of the drier were adjusted respectively at $200^{\circ} \mathrm{C}$ and $80^{\circ} \mathrm{C}$. Powder was collected in a single cyclone separator. Each sample of spray dried bacteria was rehydrated to original volume with water, phosphate buffer, MRS and skim milk at $4^{\circ}, 20^{\circ}$, $37^{\circ}$ and $50^{\circ} \mathrm{C}$. The cells were allowed to rehydrate for 2 min under vigorous shaking (shaking method) or by soaking for 30 min (soaking method).

\section{Lyophilization}

Skim milk ( $11 \%$ solids) was inoculated with Lact. bulgaricus cultures previously grown to stationary phase in MRS broth. Samples were frozen at $-80^{\circ} \mathrm{C}$ in a deep freezer and then desiccated under vacuum ( $50 \mathrm{~m}$ Torr) in a Christ Alpha 1-4 freeze drier. After the lyophilization step, dried samples were rehydrated to the original volume with deionized water at $20^{\circ} \mathrm{C}$ by the shaking method.

\section{Enumeration of micro-organisms}

Survivors before and after treatment were enumerated on MRSA and/or MRSA $+\mathrm{NaCl}(0 \cdot 8 \%)$ by the drop count technique (Miles and Misra 1938). Plates were examined after incubation at $37^{\circ} \mathrm{C}$ for $48 \mathrm{~h}$.

\section{pH evolution in skim milk}

The post-stress recovery was evaluated by following changes in the $\mathrm{pH}$ of the growth medium. Changes in the $\mathrm{pH}$ were determined using standard $\mathrm{pH}$ electrodes linked to a data acquisition and automated data logging system as previously described by Lievense (1991).

\section{B-Galactosidase activity}

Cells were grown in 2\% lactose MRS broth (prepared from individual ingredients and replacing glucose with $2 \%$ lactose) for $16 \mathrm{~h}$ at $42^{\circ} \mathrm{C}$ in a shaking water bath. The cells were harvested, washed, spray dried and rehydrated using the procedure described above. 
Normal and dried-rehydrated samples (original concentration about $1 \times 10^{9}$ cells $\mathrm{ml}^{-1}$ ) were centrifuged at $5000 \mathrm{~g}$ for $10 \mathrm{~min}$ at $4^{\circ} \mathrm{C}$. The supernatant fluids (after filter sterilization) and cell pellets (resuspended in $20 \mathrm{ml}$ of AM buffer) were used to measure $\beta$-galactosidase activity by the method described by Citti et al. (1965).

The specific activity of $\beta$-galactosidase is expressed as $\mu$ mol of $\theta$-nitrophenol liberated from $\alpha$-nitrophenyl- $\beta$-Dgalactopyranoside (ONPG) per mg of cell dry weight per min.

Total activity of each sample was determined by permeabilizing the cells with toluene (Citti et al. 1965) before the $\beta$-galactosidase assay. Total activity was considered as $100 \%$.

\section{Loss of $260 \mathrm{~nm}$ and $280 \mathrm{~nm}$ absorbing materials from the cells}

Normal and spray dried-rehydrated samples (original concentration about $1 \times 10^{9}$ cells $\mathrm{ml}^{-1}$ ) were centrifuged at $5000 \mathrm{~g}$ for $10 \mathrm{~min}$ at $4^{\circ} \mathrm{C}$ and the supernatant fluids were used to read the optical density at 260 and $280 \mathrm{~nm}$, after filter sterilization, using deionized water as a blank, in a Shimadzu UV-265 spectrophotometer. Supernatant fluids were diluted with deionized water to give an optical density reading below $1 \cdot 0$.

\section{Protein determination}

The cells were harvested, washed, spray dried and rehydrated using the procedure described above. Normal and dried-rehydrated samples (original concentration about $1 \times 10^{9} \mathrm{cells}^{-1}$ ) were centrifuged at $5000 \mathrm{~g}$ for $10 \mathrm{~min}$ at $4^{\circ} \mathrm{C}$ and the supernatant fluids, after filter sterilization, were used to determine protein concentration $\left(\mathrm{mg} \mathrm{ml}^{-1}\right)$ by the method of Lowry et al. (1951).

\section{Potassium determination}

The cells were harvested, washed with deionized water, spray dried and rehydrated using the procedure described above. Normal and dried-rehydrated samples (original concentration about $1 \times 10^{9} \mathrm{cells}^{-1}$ ) were centrifuged at $5000 \mathrm{~g}$ for $10 \mathrm{~min}$ at $4^{\circ} \mathrm{C}$ and potassium concentration in the supernatant fluids, after filter sterilization, was determined using a Jenway PFP7 flame photometer. Blanks consisted of deionized water.

\section{Statistical analysis}

Assuming a normal distribution, data were analysed using a Student's $t$-test. Significance was declared at $P<0.05$ (Box et al. 1978).

\section{RESULTS}

The evolution of $\mathrm{pH}$ in skim milk following spray drying and freeze drying was determined. No significant differences were obtained between the two samples either in terms of survival (Table 1) or in terms of rate of acid production (Figs 1 and 2). Results did, however, show that both treatments affected survival, acid production and lag phase as compared to controls.

Results for the determination of membrane permeability all demonstrated that it had increased. The first three methods used were based on leakage of intracellular constituents into the surrounding environment while the last two methods were based 'on the altered permeability of the cytoplasmic membrane to $\mathrm{NaCl}$ and ONPG (Table 2).

The effect of age on the survival of Lact. bulgaricus during spray drying is illustrated in Table 3 . Cells at stationary phase are significantly $(P<0.05)$ more resistant than cells at exponential phase.

Table 1 Survival of Lactobacillus bulgaricus at stationary phase in the production of dried cell concentrates by spray drying and lyophilization in milk

\begin{tabular}{|c|c|c|c|}
\hline \multicolumn{2}{|c|}{$\begin{array}{l}\text { Spray dried cells } \\
\log \mathrm{cfu} \mathrm{ml}^{-1}\end{array}$} & \multicolumn{2}{|c|}{$\begin{array}{l}\text { Lyophilized cells } \\
\log \mathrm{cfu} \mathrm{ml} \mathrm{m}^{-1}\end{array}$} \\
\hline B & $\mathbf{A}$ & B & A \\
\hline 8.74 & $8 \cdot 16$ & $9 \cdot 83$ & $9 \cdot 21$ \\
\hline \multicolumn{4}{|c|}{ Log reduction } \\
\hline & & & \\
\hline
\end{tabular}

B, Before drying; A, after drying.

Rehydration was performed by the shaking method



Fig. 1 pH evolution in milk. $\Delta$, Before spray drying; $O$, after spray drying 
Table 2 Evidence of membrane damage as indicated by developed sensitivity to $\mathrm{NaCl}$, increased $\beta$-galactosidase activity and leakage of cellular materials in spray dried Lactobacillus bulgaricus at stationary phase having maltodextrin as suspending liquid

\begin{tabular}{|c|c|c|}
\hline Manifestations* & Normal cell & Spray-dried cell \\
\hline \multicolumn{3}{|l|}{$\begin{array}{l}\text { Absorbancy of } \\
\text { supernatant fluid at: }\end{array}$} \\
\hline $260 \mathrm{~nm}$ & $2 \cdot 876$ & ${ }^{b} 3 \cdot 832$ \\
\hline $280 \mathrm{~nm}$ & ${ }^{a} 1.942$ & b $2 \cdot 280$ \\
\hline Protein ( $\mathrm{mg} \mathrm{m} \mathrm{ml}^{-1}$ ) in supernatant fluid & ${ }^{\mathrm{a}} 0 \cdot 382$ & ${ }^{\mathrm{a}} 0 \cdot 460$ \\
\hline$K$ (ppm) in supernatant fluid & ${ }^{a} 20 \cdot 2$ & ${ }^{b} 45 \cdot 13$ \\
\hline \multicolumn{3}{|l|}{$\% \beta$-galactosidase activity in: } \\
\hline Cell suspension & 33.5 & ${ }^{b} 83 \cdot 5$ \\
\hline Cell supernatant fluid & ${ }^{\mathrm{a}} 0$ & ${ }^{\mathrm{b}} 1.04$ \\
\hline Permeabilized cell & 100 & - \\
\hline$\%$ Sensitivity to $\mathrm{NaCl}$ & ${ }^{a} 21 \cdot 11$ & b72.50 \\
\hline
\end{tabular}

* Average of four experiments.

a,b Means with different superscripts in the same row differ $(P<0.05)$.



Flg. $2 \mathrm{pH}$ evolution in milk. $\triangle$, Before lyophilization; , after lyophilization

The effect of heat shock on the resistance to spray drying was evaluated as a function of the age of the cells (Table 4). When cells are heat shocked at stationary phase there is no increase in the resistance to the subsequent drying. Heat

Table 3 Effects of age on survival of Lactobacillus bulgaricus during spray drying in milk

\begin{tabular}{lll}
\hline & \multicolumn{2}{l}{ Log cfu ml } \\
\cline { 2 - 3 } Phase of growth & Before drying & After drying \\
\hline Stationary & ${ }^{\mathrm{a}} 8.87$ & ${ }^{\mathrm{a}} 7.45$ \\
Exponential & $\mathrm{a} 8.54$ & ${ }^{\mathrm{b}} 5.80$ \\
\hline
\end{tabular}

* Average of three experiments.

$a, b$ Means with different superscripts in the same column differ $(P<0.05)$.

Rehydration was performed by the shaking method.
Table 4 Effect of heat shock on the survival of Lactobacillus bulgaricus at different stages of growth during spray drying in milk

\begin{tabular}{llllll}
\hline & \multicolumn{2}{l}{$\begin{array}{l}\text { Heat shocked cells } \\
\text { log cfu ml }\end{array}$} & & \multicolumn{2}{l}{$\begin{array}{l}\text { Control cells* } \\
\log \mathrm{cfu} \mathrm{ml}^{-1}\end{array}$} \\
\cline { 2 - 3 } \cline { 5 - 6 } Phase of growth & $\mathrm{B}$ & $\mathrm{A}$ & & $\mathrm{B}$ & $\mathrm{A}$ \\
\hline Stationary & 8.72 & 7.14 & & 8.59 & 7.37 \\
Exponential & 8.26 & ${ }^{\mathrm{a}} 6.05$ & & 8.53 & ${ }^{\mathrm{a}} 5.87$ \\
\hline
\end{tabular}

a Means with superscripts in the same row differ $(P<0 \cdot 05)$.

B, Before drying; A, after drying.

* Average of three experiments.

Rehydration was performed by the shaking method.

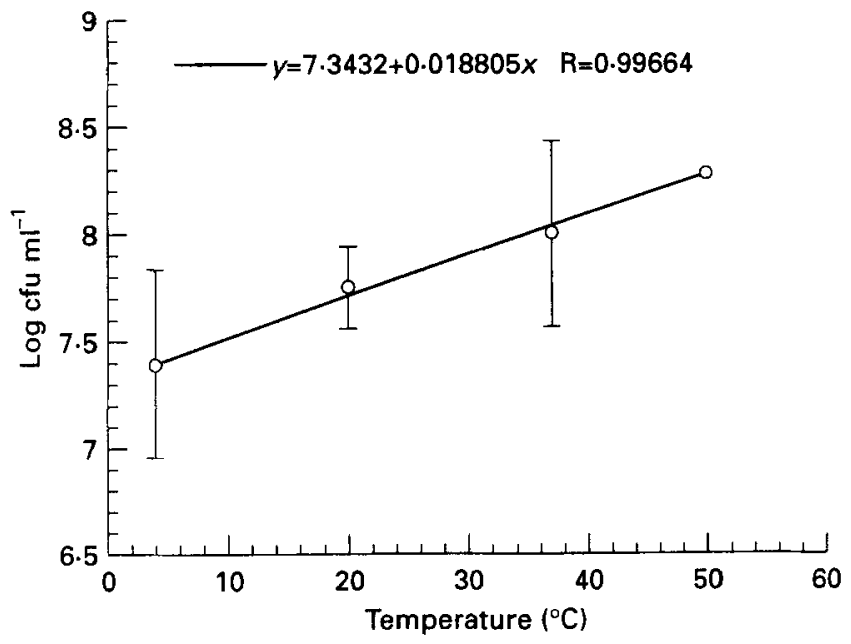

Fig. 3 Influence of rehydration temperature (shaking method) on the recovery of spray dried stationary phase cells. Vertical bars indicate overall standard errors of the mean 
Table 5 Influence of different rehydration media, at $20^{\circ} \mathrm{C}$, on the survival of spray dried Lactobacillus bulgaricus at stationary phase having milk as carrier suspension

\begin{tabular}{lllll}
\hline $\begin{array}{l}\text { Rehydration } \\
\text { media }\end{array}$ & $\begin{array}{l}\text { Skim } \\
\text { milk }\end{array}$ & $\begin{array}{l}\text { Phosphate } \\
\text { buffer }\end{array}$ & $\begin{array}{l}\text { MRS } \\
\text { broth }\end{array}$ & $\mathrm{H}_{2} \mathrm{O}$ \\
\hline L.og cfu ml $^{-1 *}$ & 7.40 & 7.21 & 7.00 & 7.30 \\
\hline
\end{tabular}

* Average of three experiments.

Rehydration was performed by the shaking method.

shocked exponential phase cells significantly $(P<0 \cdot 05)$ increase their resistance to the process as compared to control cells.

The influence of rehydration temperature on the rccovery of dried cells was investigated. Survival rate increases linearly with temperature between $4^{\circ} \mathrm{C}$ and $50^{\circ} \mathrm{C}$ (Fig. 3).

Recovery of Lact. bulgaricus was investigated as a function of the rehydration media. No significant differences $(P<0.05)$ were detected when skim milk, MRS broth, deionized water or phosphate buffer were used (Table 5).

Two different methods of rehydration were compared. Higher recovery was obtained when cells were slowly rehydrated (Table 6).

\section{DISCUSSION}

Lyophilized and spray dried cells showed similar survival and acid production following treatment. It was therefore decided to investigate the reasons for loss of viability in spray dried cells. In order to study membrane damage, a model system using maltodextrin was used as the suspending liquid. Survival in both maltodextrin and skim milk was similar indicating that mechanisms of damage in the two systems are the same.

Previous workers have reported cytoplasmic membrane damage for a wide range of stress conditions including Allwood and Russell (1968), Strange and Cox (1976), Brennan et al. (1986) and Ray (1993).

All of the methods used here, 260 and $280 \mathrm{~nm}$ absorbing material, $\mathrm{K}^{+}$and $\beta$-galactosidase leakage, all strongly indicate that membrane damage in stationary phase cells occurs

Table 6 Influence of rehydration method, at $20^{\circ} \mathrm{C}$, on the survival of Lactobacillus bulgaricus at stationary phase following spray drying in milk

\begin{tabular}{ll}
\hline Rehydration method & Log $\mathrm{cfu} \mathrm{ml}^{-1 *}$ \\
\hline Soaking & 77.95 \\
Shaking & 77.28 \\
\hline
\end{tabular}

* Average of three experiments.

a,b Means with different superscripts differ $(P<0.05)$. during spray drying. Increased sensitivity to $\mathrm{NaCl}$ further reinforces this conclusion although universal agreement on the effect of this compound after entering into the cytoplasm has not been reached (Morichi and Irie 1973; Hurst et al. 1973; Hurst and Hughes 1981). The above methods for leakage, however, do not allow for the distinction of leaked material from sublethally damaged or lysed (dead) cells. It is important to stress that the method of Brennan $e t$ al. (1986) allows for this differentiation with the penetration of ONPG being facilitated in damaged cells.

Cells at stationary phase are significantly more resistant to spray drying than cells at exponential phase. Similar results were obtained heating of Lact. bulgaricus in skim milk at different temperatures (Teixeira et al. 1994). The increased resistance of stationary phase cells to spray drying could be explained in terms of physiology such as the reduced amount of replicating DNA (Mirhabibollahai 1988) or in terms of acid-shock (Farber and Pagotto 1992). Kirby (1990) showed that dehydrated cells of Salmonella typhimurium were more resistant to heating at $135^{\circ} \mathrm{C}$ if subjected to amino acid starvation when compared to the unstarved control cells. Heat shock increased the survival of exponential cells as compared to controls but did not result in normal levels found with unshocked stationary phase cells. Heat shock had no effect on stationary phase cells. The same fact was observed with the same organism during heating in skim milk (Teixeira et al. 1994). It was therefore concluded that the differences in recovery were not of sufficient magnitude to merit further investigation.

The effect of the rehydration temperature on the recovery of spray dried Lact. bulgaricus was investigated. Survival rate increased linearly as the temperature of rehydration increased, with the difference between $4^{\circ} \mathrm{C}$ and $50^{\circ} \mathrm{C}$ being less than a $\log$ cycle. Speck and Myers (1946) also concluded that $50^{\circ} \mathrm{C}$ was the temperature allowing higher recovery after spray drying. Studying the effect of rehydration temperature on the survival of freeze dried lactic acid bacteria, de Valdez et al. (1985) determined $20^{\circ} \mathrm{C}$ as the optimum rehydration temperature. Similar results were obtained by Speck and Myers(1946). These results indicate that physiological differences between freeze dried and spray dried cells of Lact. bulgaricus may exist.

Rehydration media was evaluated on the recovery of spray dried Lact. bulgaricus. Although milk and MRS broth might supply a large variety of nutrients no significant differences were found when rehydration was carried on phosphate buffer or deionized water. Ray et al. (1971) found similar results during rehydration of freeze dried Salmonella anatum and proposed that milk may have supplied all nccessary nutrients to the injured cells and thus masked any effects of various added nutrients (MRS broth). Effects of nutrient deficiency (water and phosphate buffer) may also be masked by the same fact. 
Significant differences were obtained when cells were rapidly or slowly rehydrated. This is in agreement with results obtained by other investigators (van Schothorst $e t$ al. 1979; Ray et al. 1971). van Schothorst et al. (1979) proposed that the soaking procedure limited the amount of osmotic shock leading to higher recovery. Ray et al. (1971) proposed that some structure(s) necessary for the cell integrity may be damaged in spray drying. By controlling the rate of rehydration, the disruption of the cells may be reduced. Results do suggest that post-stress lethality as a result from osmotic shock during rehydration may play a role in reducing viable counts.

By comparison of the two methods, spray drying and freeze drying, in terms of survival, acid production and extent of the lag phase, no significant differences were obtained. For this reason, the authors think that it is possible and advantageous, at least with Lact. bulgaricus, to concentrate starter cultures by spray drying. In the scope of these results and other of previous investigators, in order to obtain a high number of viable cells of Lact. bulgaricus in a spray dried concentrate, it is recommended to dry the cells at the stationary phase of growth and to use slow rehydration procedures. Further investigation is necessary to try to protect the membrane from injury.

\section{REFERENCES}

Allwood, M.C. and Russell, A.D. (1968) Thermally induced ribonucleic acid degradation and leakage of substances from the metabolic pool in Staphylococcus aureus. Journal of Bacteriology 95, 345-349.

Box, G.E.P., Hunter, W.G. and Hunter, J.S. (1978) Statistics for Experimenters. An Introduction to Design, Data Analysis, and Model Building. New York: John Wiley.

Brennan, M., Wanismail, B., Johnson, M.C. and Ray, B. (1986) Cellular damage in dried Lactobacillus acidophilus. Journal of Food Protection 49, 47-53.

Citti, J.E., Sandine, W.E. and Elliker, P.R. (1965) $\beta$ - Galactosidase of Streptococcus lactis. Journal of Bacteriology 89, 937-942.

de Valdez, G.F., de Giori, G.S., Holgado, A.A.P.D.R. and Oliver, G. (1985) Effect of rehydration temperature on the survival of freeze-dried lactic acid bacteria. Milchwissenschaft 40, 147-148.

Espina, F. and Packard, V.S. (1979) Survival of Lactobacillus acidophilus in a spray-drying process. Journal of Food Protection 42, 149-152.

Farber, J.M. and Pagotto, F. (1992) The effect of acid shock on the heat resistance of Listeria monocytogenes. Letters in Applied Microbiology 15, 197-201.

Foster, E.M. (1962) Culture preservation. Journal of Dairy Science 45, 1290-1294.

Gilliland, S.E. (1976) Preparation and storage of concentrated cultures of lactic streptococci. Journal of Dairy Science 60, 805809.

Griffiths, R.P. and Haigh, R.D. (1973) Reversible heat injury in the marine psychrophilic bacterium Vibrio marinus. Canadian Journal of Microbiology 19, 557-561.
Hogg, T. (1989) Effects of heat shock on the survival of Salmonella typhimurium. PhD Thesis, University of Reading, UK.

Hoover, D.G. and Gray, R.J.H. (1977) Function of cell wall teichoic acid in thermally injured Staphylococcus aureus. Journal of Bacteriology 131, 477-485.

Hurst, A. and Hughes, A. (1975) Loss of D-alanine during sublethal heating of Staphylococcus aureus s6 and magnesium binding during repair. Journal of General Bacteriology 89, 277284.

Hurst, A. and Hughes, A. (1981) Repair of salt tolerance and recovery of lost D-alanine and magnesium following sublethal heating of Staphylococcus aureus are independent events. Canadian Journal of Microbiology 27, 627-632.

Hurst, A., Hughes, A., Beare-Rogers, J.L. and Collins- Thompson, D.L. (1973) Physiological studies on the recovery of salt tolerance by Staphylococcus aureus after sublethal heating. Journal of Bacteriology 116, 901-907.

Hurst, A., Hughes, A. and Collins-Thompson, D.L. (1974) The effect of sublethal heating on Staphlococcus aureus at different physiological ages. Canadian Journal of Microbiology 20, 765768.

Kim, S.S. and Bhowmik, S.R. (1990) Survival of lactic acid bacteria during spray drying of plain yoghurt. Journal of Food Science 55, 1008-1010.

Kirby, R.M. (1990) The survival of salmonellae during chocolate mass production. $\mathrm{PhD}$ Thesis, University of Reading, UK.

Lievense, L.C. (1991) The inactivation of Lactobacillus plantarum during drying. PhD Thesis Uniliver Research Laboratory, The Netherlands.

Lowry, O., Rosebrough, N.J., Farr, A.L. and Randall, R.J. (1951) Protein measurement with the Folin phenol reagent. Journal of Biological Chemistry 193, 265-275.

Mamaeva, P. (1956) Dry Koumiss culture. Dairy Science Abstract $18,639$.

Miles, A.A. and Misra, S.S. (1938) The estimation of the bactericidal power of blood. Journal of Hygiene 38, 732-749.

Mirhabibollahai, B.M. (1988) The effect of mode of DNA replication on the resistance of Salmonella typhimurium LT2 to physical stress. PhD Thesis, University of Reading, UK.

Morichi, T. and Irie, R. (1973) Factors affecting repair of sublethal injury in frozen or freeze-dried bacteria. Cryobiology 10 , 393-399.

Morichi, T., Irie, R., Yano, N. and Kembo, H. (1967) Death of freeze-dried Lactobacillus bulgaricus during rehydration. Agricultural and Biological Chemistry 31, 137-141.

Porubcan, R.S. and Sellars, R.L. (1975) Spray drying of yoghurt and related cultures. Journal of Dairy Science 58, 787.

Prajapati, J.B., Shah, R.K. and Dave, J.M. (1987) Survival of Lactobacillus acidophilus in blended-spray dried acidophilus preparations. Australian Journal of Dairy Technology 42, $17-21$

Ray, B. (1993) Sublethal injury, bacteriocins, and food microbiology. Features 59, 285-291.

Ray, B., Jezeski, J.J. and Busta, F.F. (1971) Effect of rehydration on recovery, repair, and growth of injured freeze-dried Salmonella anatum. Applied Microbiology 22, 184-189.

Richardson, G.H. (1960) Studies involving the preservation of a lactic culture. PhD Thesis, University of Wisconsin, USA. 
Rogers, I.A. (1914) The preparation of dried cultures. Journal of Infectious Diseases 14, 100-123.

Speck, M.L. and Myers, R.P. (1946) The viability of dried skimmilk cultures of Lactobacillus bulgaricus as affected by the temperature of reconstitution. Journal of Bacteriology 52, 657-663.

Strange, R.E. and Cox, C.S. (1976) Survival of dried and airborne bacteria. In The Survival of Vegetative Microbes ed Gray, T.R.G. and Postgate, J.R. pp. 111-154. Cambridge, UK: Cambridge University Press

Teixeira, P., Castro, H. and Kirby, R. (1994) Inducible thermo- tolerance in Lactobacillus bulgaricus. Letters in Applied Microbiology 18, 218-221.

van Schothorst, M., van Leudsen, F.M., de Gier, E., Rijnierse, V.F.M. and Veen, A.J.D. (1979) Influence of reconstitution on isolation of Salmonella from dried foods. Journal of Food Protection 42, 936-937.

Whitaker, R.D. and Batt, C.A. (1991) Characterisation of the heat shock response in Lactococcus lactis subsp. lactis. Applied and Environmental Microbiology 57, 1408-1412. 